\title{
Control of Spruce Budworm Damage by Aerial Spraying with Insecticides ${ }^{1}$
}

Every thinking person should be concerned about the possible consequences of spraying insecticides from the air over huge areas. The results - good, bad and unknown - are so farreaching that no one can foresee their ultimate effects. My purpose in presenting this brief is to plead for a balanced view of the risks and benefits involved. It is abundantly clear that the choice now confronting us is one between two very unpleasant evils. Nevertheless, before that choice is made, let us be very sure indeed that we have made every effort to assess objectively and without emotion or alarmism the impact which will follow any of the few options open to us. I take this opportunity to make a small contribution to such an assessment.

Because others have already stressed the tremendous economic importance of the forestbased industries to every New Brunswicker whether he realizes it or not, I shall not belabour that aspect of the problem. However, I shall draw some economic comparisons in order to bring into perspective some of our value judgements concerning this controversial topic. But first I want to speak of the environment.

I shall start by relating a personal experience. In the spring and early summer of 1927 I spent some weeks in part of the watershed of the Upsalquitch which had been severely damaged by the budworm infestation that occurred around the end of World War I. The area was burned in 1923 in one of this Province's major forest fires of the century. The size of this burn was reported to be about 400 square miles - a mere "patch" compared with the extent of the current budworm infestation.

Here and there in the valley bottoms some timber had escaped the flames and was green, but the rest was a desolate waste. I do not recall ever seeing in it a living mammal, reptile or resident bird. Even insects were scarce, and there was precious little living vegetation of any kind. It was a drab, brown and grey world. What I do recall seeing in abundance was soil erosion the effects of which are still in evidence and will remain so for many years yet to come. I wonder if there was ever a more "silent spring" anywhere except in a desert. Certainly I hope I never experience its like again.

It is commonly believed that the clear-cutting of timber is responsible for floods. That can be so only if the clear-cuts extend over a very large part of a major watershed. However, severe and widespread deforestation of the kind which would result from uncontrolled destruction by the present budworm outbreak would have a markedly adverse influence on the patterns of run-off of some of the larger rivers of the Province.

As a generality, it can be said that there is no conclusive evidence that budworm-killed timber creates conditions unduly favourable to the incidence of forest fires. Yet the known facts strongly suggest that the potential for high inflammability can be so generated, at least for a short period of years. If this state should happen to coincide with appropriate weather conditions, it could result in an abnormally high risk of a major conflagration. I cannot demonstrate that the budworm-kill was the direct or indirect cause of the Upsalquitch fire of 1923. Still less can I show that the budworm outbreak at about the beginning of the nineteenth century contributed to the start of the Miramichi holocaust of 1825. But what can be said with certainty is that, in both cases, a badly budwormed forest or a forest which followed a budworm infestation sustained and carried fire over phenomenally large areas - an area estimated to have been about 8000 square miles in the case of the Miramichi fire. It seems to me that it would be prudent to assume that there is a relationship between budworm-killed forest and the susceptibility to the incidence and spread of fire until such time as the examples I have cited can be shown to be only coincidences.

The message I have tried to convey thus far is this. Even though aerial spraying with insecticides has killed some birds, fish, bees and probably other wild things, and even supposing that budworm-spraying is some day proven to contribute to the incidence of skin cancer and/or Reye's syndrome, it certainly does not follow that halting the spray program will put an end to hazards to animal life. On the contrary, bird and fish and bee populations could be reduced far more and a greater number of human lives could be placed in jeopardy from fire and flood as a result of not spraying. I submit that, if we look unemotionally and objectively at both sides of the budworm-spraying "coin", it is the "no-spray" side which appears to hold by far the more serious environmental threats - let alone the frightening economic ones.

Without I myself putting a dollar sign on the value of human life and health, I feel I must say something on this touchy subject. Much as we may hate to admit the fact, society places monetary values on these things every day. We may say that no amount of forest saved is worth a single human life, but we do not act by that tenet. Every year many people are accidentally electrocuted; we do not ban the use of electricity. It is well known in the construction industry that, on the average, a life will be accidentally lost for every " $X$ " million dollars worth of construction; we still build. Every year miners by the score are killed underground; we continue to mine. These activities are not pursued as a

\footnotetext{
1. A brief by E.S. Fellows presented to the select committee of the New Brunswick Legislature on Renewable Resources. We share the opinion of the Maritime section of the ClF that these thoughts on the budworm problem will be of interest to readers.
} 
result of a cold-blooded callousness; they are carried on for the welfare of mankind at large. Electricity, construction, coal and iron save lives and improve health as well as bringing death to an ill-fated few. I suggest that green forests also preserve lives and improve health, and it has yet to be proved that spraying to keep them green in New Brunswick has taken either life or health except for a few unfortunate spray-plane pilots.

Every year society makes great efforts and spends much money to reduce the number of people killed by electrocution, construction accidents, mining accidents, automobile accidents, and many other forms of unnecessary death. By all means let us do the same in relation to the real risks in budworm spraying. At the same time, let us be very conscious not only of the inestimable benefits the green and living forests confer on every New Brunswicker, but also of the environmental, as well as the economic, price we shall pay if we allow much of it to perish.

To place things in perspective, let me advance this proposition. It seems that recently, on the average, Reye's syndrome has taken the lives of one or two New Brunswick boys and girls each year, which is the same per capita incidence as that for North America as a whole - a deathrate statistically comparable to that from lightning strikes, appendicitis or mental retardation. In the five years from 1971 through 1975 there have been in New Brunswick an annual average of 39 deaths amongst children 14 years of age and under attributable to motor-vehicle accidents. In the same period the same cause has brought injury to 2797 children in the same agegroup. In 1974 and 1975 alone some 517 persons of all ages were killed in motor-related accidents, and a further 9524 persons were injured in them. If it makes good sense to allow the forest to be ravaged and basic industries to be permanently closed in order that one or two deaths a year from Reye's syndrome may perhaps be prevented, how much more sense would it make to ban all motor vehicles in New Brunswick in order to save almost 260 lives (about 40 of them children) known to be lost each year in motor-vehicle accidents?

Last year a distraught mother was interviewed on a local radio station on the topic of budworm spraying. She was so upset over the hazard this activity posed to her children's health that she had decided to drive them to Nova Scotia to stay until the spraying ended and then to drive them home again. In light of the above-cited incidence of deaths from Reye's syndrome (whatever its cause) and from motor-vehicle accidents, I leave it to the members of your Committee to judge for yourselves the rationality of this lady's decision. Sad to say, it is just this sort of lack of realism which is colouring much of the public's attitude towards spruce-budworm spraying.

It has been proposed that budworm spraying should be halted until an alternative control method is found which is irrefutably safe for hu- mans, birds, animals and insects other than the budworm. By that time, the spruce - fir forest will have disintegrated and the bulk of the forest industries with them.

Some of those who advocate an end to the budworm-spraying program contend that the problem should be solved by better forest management. The plain fact is that, if the spruce fir forests of New Brunswick are now surrendered to the budworm, no conceivable forest-management practice could prevent the stage from being set for another budworm infestation of comparable dimensions in about 40 or 50 years time - and so on ad infinitum. It is still debatable how much forest management can achieve in controlling budworm outbreaks. However, it is certain that control by management is all but impossible if the forest consists of trees of a single age-class It is just such a forest that a budworm-kill creates, and that is one very good "forest management" reason why wholesale budworm-kills must be prevented at any reasonable cost. It is the budworm which is chiefly responsible for the fact that we have too much over-aged forest; until we have learned how to control this insect, that situation will recur again and again.

The medical profession is properly concerned over public health and safety. If some mice painted with No. 2 fuel oil three times a week for 21 months develop skin cancer, doctors are clearly right to warn of a hazard; indeed they would be wrong to do otherwise no matter how small the risk to humans may be. What the medical profession is not justified in doing, however, is to recommend an action (or inaction) involving other hazards to human life and welfare on which it is not competent to pass judgement.

A small group which has arrogated to itself the right to use capital initial letters to distinguish its members from the thousands of other concerned parents in the Province who happen to disagree with them has pressed the "panic button" over budworm-spraying. They would have us believe that putting an end to the spraying program would thereby put an end to environmental damage and to danger to life and health attributable to the budworm. That is simply not true, and they do a serious public disservice by suggesting that it is.

It is the unenviable duty of your Committee to make an objective assessment of the balance of risks and benefits involved in spraying and in not spraying. A further unpleasant aspect of this responsibility is the knowledge that a "no-spray" decision would leave little opportunity for "second thoughts". Most of the environmental consequences of spraying can be ended at will by putting a stop to spraying. Unfortunately the environmental consequences of not spraying are irreversible and cannot be stopped by man they must run their course.

Should you desire to question me on this brief, I shall make myself available. In any event, I wish you well in your deliberations. 